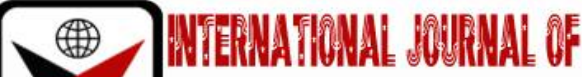

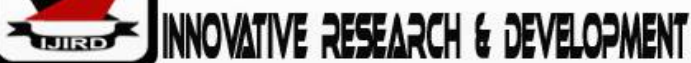

ISSN 2278 - 0211 (Online)

\section{Effect of External Debt on Economic Growth in Kenya: Vector Error Correction Model (VECM) Approach}

\author{
Francis Sirare Marwa \\ Assistant Manager, Department of Finance, Kenya Bureau of Standards, Nairobi Kenya
}

\begin{abstract}
:
The study examined relationship between external and economic growth in Kenya from 1980-2017. The study embraced the VECM to analyze data. "The variables in the research comprised of RGDP, "Bilateral Debt (BLEDT), Multilateral Debt (MLEDT) and Suppliers Credit (SCRDT). The outcome exhibited that Bilateral Debt (BLEDT) Multilateral Debt (MLEDT) have negative relation with GDP growth in Kenya both in the short- run and long- run. On the other hand, suppliers Credit (SCRDT) has a positive relationship with GDP growth in Kenya in the long-run and in the short-run, it has insignificant relationship with GDP growth in Kenya under the period of study. There is causal relationship among variables, there is unidirectional causality running from RGDP to BLEDT and there is unidirectional causality running from RGDP to SCRDT.

From the findings, the study suggests that the government should maintain sustainable level of external debt in order to achieve desirable level of GDP growth. The external debt obtained by the government should be allocated strictly to capital projects such as infrastructure development.
\end{abstract}

Keywords: External debt, economic growth, bilateral debt, multilateral debt, suppliers credit, granger causality

\section{Background of the Study}

Less developed countries desire significant and consistent economic growth. This desire can be achieved through expansion of basic infrastructure. The development in these countries was intended to raise average income per capita. Unfortunately, many developing countries have not made significant progress towards this end. The historical progress in the recent past indicated that income per is falling, rising hunger and environmental pollution (Woo, \& Kumar,2015).

Developing countries have continued to rely on external debt to achieve sustainable economic growth. However, external debts have resulted in large repayment costs. The debt service is contractual payment that a country makes towards borrowed funds. If developing countries excessively borrow, it will reach a point where they will not afford payment of debt service, which is detrimental to the country's growth (Adamu \&Rasiah, 2016). Viable level of debt will heighten development in the current period, however, in the final analysis it will lead to economic deterioration among countries. External debt if applied in capital-oriented project such as infrastructure and long-term social programs can lead to desirable outcomes in terms of promoting GDP growth (Megersa, 2015).

\subsection{External debt stock in Kenya}

Kenya foreign debt stood at Ksh 2.4 trillion as at 2017/ 2018. "This was an increase from Ksh 2.1 trillion in June 2017". This translated to an upsurge of external debt stock by 12.6\%. The upsurge was due to increase in international sovereign bonds disbursement, commercial syndicated loans and bilateral creditors disbursements (Republic of Kenya, National Treasury, 2018).

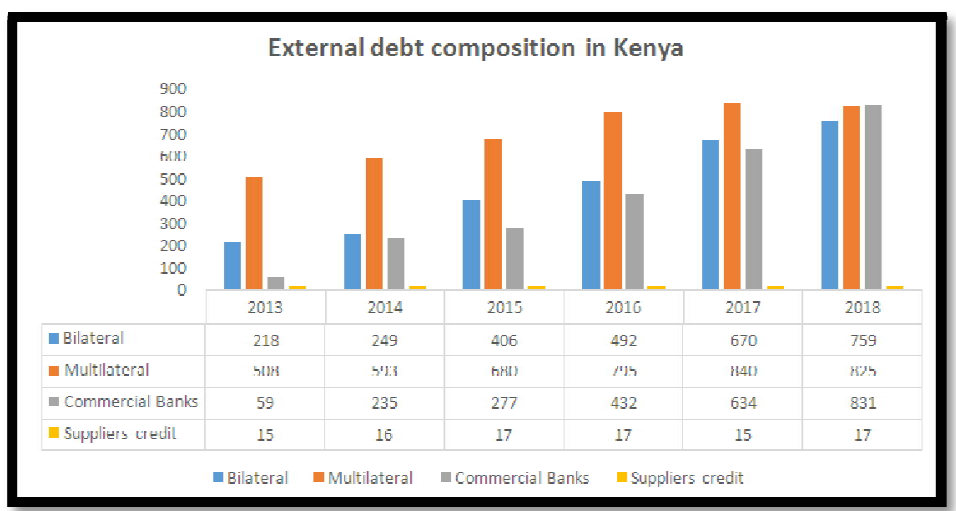

Figure 1: External Debt Composition in Kenya 
Generally, external debt increased since the issuance of Eurobond. From the above figure, 1 there has gradual increase in multilateral while bilateral debts have been decreasing.

Stock of commercial debt has gradually increased since the debut Eurobond. In the same period, there has been gradual increase in multilateral debt while bilateral debt exhibited a declining trend.

The loans from foreign commercial banks have been growing for instance in the year 2018 commercial bank loans expanded by $4.6 \%$.

\subsection{Gross Domestic Product Growth Rate}

Kenya experienced a negative economic performance growth of $-4.66 \%$ in 1970. This trend reversed in 1971 where the growth up to $22 \%$ and $17 \%$ in 1972. From 1973, the economic performance declined to $0.88 \%$ in 1975 . From 1991 to 1993 experienced the worst economic performance where the annual growth rate was $1.44 \%$ in 1991 and $-0.8 \%$ in 1992. During this period GDP growth stagnated, agricultural production decreased, inflation hit 100\% and government budget deficit was more than $10 \%$ of the GDP (Mwaniki, 2016).

The growth of GDP improved in 2004 and 2005 the country achieved a growth of $5.1 \%$ and $5.9 \%$ respectively. This growth in 2004 and 2005 was due to expansion in hospitality, service industry and construction and recovery of construction sector". In 2007, growth rate was $6.85 \%$ and due to post election violence in 2008 , the country realized a paltry $0.23 \%$. The GDP growth rate in 2015 was $5.72 \%$, "while 2016 the country posted a growth rate of 5.87\%". The slight improvement in GDP growth was due to stable macroeconomic environment, robust improvement in agricultural inputs, growth in construction sector, finance and insurance and real estate (Mwaniki,2016).

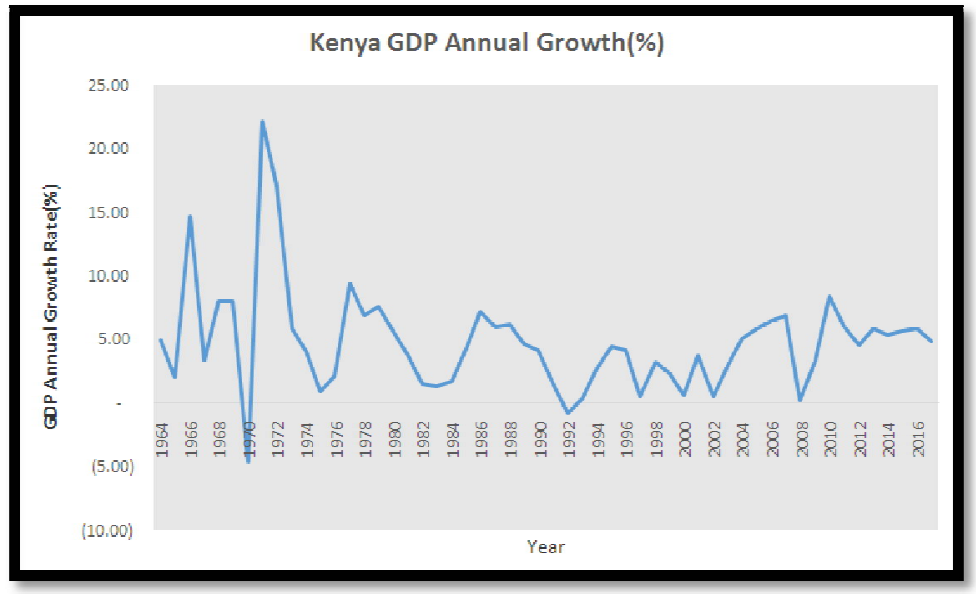

Figure 2: Kenya GDP Annual Growth

\subsection{Statement of the Problem}

Foreign debt in Kenya has been on the increasing trend in the past ten years. In the year 2017 public debt stood at Kshs.2.1 trillion, that is about 30\% of the national output (Central Bank of Kenya, 2018). The rapid growth in external debt in Kenya is attributed to infrastructure related borrowing; this was meant to spur productive capacity of the country. On the other side, high levels of external debt in a country can lead to a crisis and can pose serious risks touching on RGDP growth and financial stability (Mwaniki, 2016). In addition, high external debt can hinder a government from delivering on its development and social programs, since large government, expenditure is used to pay back external debt in the form of servicing charges and interest, and it can lead to higher taxes to repay existing debts (Blake, 2015). Therefore, the drive of this study was to establish the extent to which external debt affects RGDP growth in Kenya.

\subsection{General Research Objective}

The general objective was to examine and establish the consequences of high level of external debt on RGDP growth in Kenya

\subsubsection{Specific Research Objectives.}

The specific objectives of the study were as follows:

- To establish the impact of Bilateral debt on GDP growth in Kenya

- To establish the impact of multilateral debt on GDP growth in Kenya

- To establish the impact of Supplier credit on GDP growth in Kenya

\subsection{Research Hypotheses}

The following research hypotheses were tested:

- $\mathrm{H}_{1}$ : Bilateral debt does not significantly affect RGDP growth in Kenya.

- $\mathrm{HO}_{2}$ : Multilateral debt does not significantly affect RGDP growth in Kenya.

- $\mathrm{HO}_{3}$ : Supplier credit does not significantly affect RGDP growth in Kenya 


\subsection{Justification of the Study}

The end result of this study will assist policy makers in understanding how external debt affect the GDP growth in Kenya and how it can enhance the nation's output growth and stability. The findings will be vital in informing policy on the appropriate and optimal debt level so the borrowing country can achieve desirable results.

\subsection{Scope of the Study}

The central point of this study was to launch how government debt affects RGDP growth in Kenya. The study focused on external debt, which consist of bilateral debt, multilateral debt, and supplier's credit. The study used time series from 1980 to 2017. The study employed the use of Vector Autoregressi on (VAR) analysis VECM model. Time series data was collected in Nairobi, Kenya.

\section{Literature Review}

\subsection{Theory of Functional Finance}

This theory stresses that the state should borrow funds as long as it is economical, for instance the government want to mob up excess liquidity from money market that by floating government bonds. This theory stresses that public debt will be desirable as long as the aggregate demand does not exceed aggregate supply leading to inflation. This theory further argues that as long the government is willing to borrow there is no economic problem with government and in the final analysis government debt impacts economic growth positively (Nadeeka, De Silva, \& Naranpanawa, 2017).

\subsection{Debt Overhang Theory}

The debt overhang theory asserts that if the public debt burden exceeds the country's repayment ability in the future, then the expected debt servicing will be an increasing function of GDP of the borrowing country (Owusu \& Erickson, 2016; Saxena \& Shanker, 2018). In such a situation, the indebted country is left with a small proportion of any increases in output and exports because part of the proceeds is used to service external debt (Upreti, 2015). On the other hand, this theory asserts that reducing debt obligation can lead to undesirable consequences. When this happens, the outstanding debt is more likely to be repaid therefore reducing chances of debt default (Hukkinen \& Viren, 2017).

Similarly, when public debt impact is huge, the indebted country suffers deleterious costs on GDP growth. Debt Laffer curve gives a description of public debt level and the country's repayment ability. This indicates that there is a maximum limit at which accumulation of public debt can promote economic growth (Krause \& Moyen, 2016; Alcidi \& Giovannini, 2015).

\subsection{Conceptual Framework}

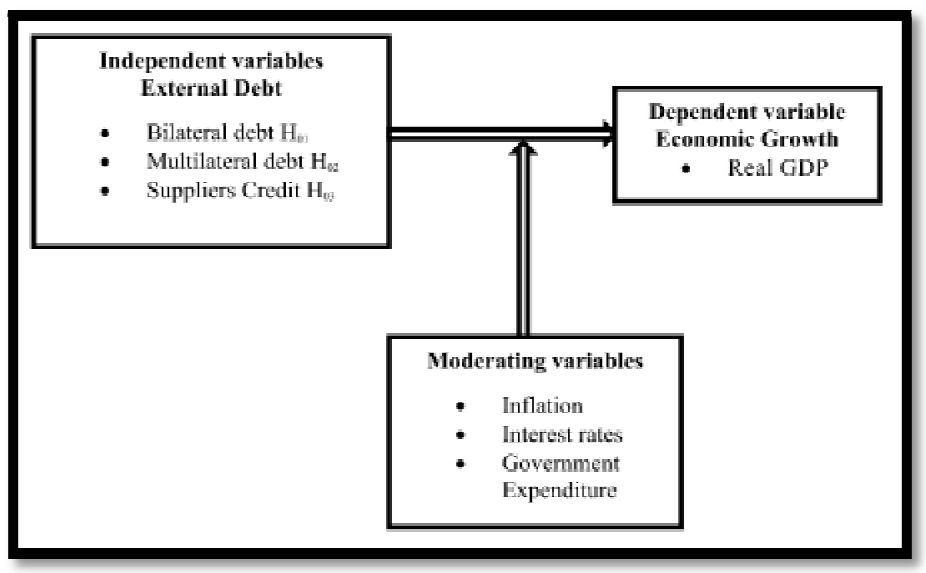

Figure 3: Conceptual Framework

\subsection{Empirical Review}

Jamaica, Senadza, Fiagbe, and Quartey (2017) studied consequences of debt on development in Africa. The study used secondary data of 39 Sub-Saharan Africa countries from the period covering 1990 to 2013. The study applied GMM estimation technique. The results showed that foreign debt and GDP in Sub-Saharan Africa are negatively correlated. They also found that external debt does not follow a linear part thus non-linear with GDP. However, the study looked at external debt only and from aggregate level without breaking down into individual components of external debt.

Doğan and Bilgili (2014) studied the non-linear impact of high and mounting state debt and GDP growth in Turkey using secondary data from 1974-2009. The study applied the use of multivariate dynamic Markov-Switching model as data analysis tool. The study confirmed that state debt and GDP growth do not follow a linear path.

Jilenga, Xu, and Gondje (2016) deliberated outcome of state debt and investment on GDP growth in Tanzania. The used secondary data from 1971-2011. The empirical analysis was based on ARDL model as data analysis tool. The findings pointed out that debt is positive accelerator of GDP growth of a country in the long-term. 
Adedoyin, Babalola, Otekunri, and Adeoti (2016) the study looked the outcome of state debt on GDP growth in Nigeria using secondary data from 1974-2014. The study employed the use of ARDL model to estimate as data analysis. The results indicated a significant association exists between government debt and GDP growth at long-term and shortterm and observed using Granger causality test whether causality or no causality exist in the study.

Mensah, Aboagye, Abor, and Kyereboah (2017) studied foreign debt among less developed countries in Africa using panel dataset from 24 African economies. Applied the use of a panel vector Autoregression methodology. The results showed that that foreign debt has positive correlation with public investment expenditure, recurrent expenditure, and internal borrowing in the long-term. While on the other hand, foreign debt has an inverse linkage with economic growth.

Ahmed (2017) considered how foreign debt impacts GDP growth in 70 third world countries from $1976-2011$. The study used regression analysis and fixed effect model as data analysis tool. The findings showed that external debt and GDP are negatively correlated. This is may be detrimental to countries with poor quality financial and monetary institutions.

Lee and Ng (2015) studied the extent to which foreign debt affects GDP growth in Malaysia for the period from 1991 to 2013 using multiple regression analysis. The cost of government borrowing was captured by budget deficits, government recurrent expenditure and foreign debt repayment cost and this was a country level study. They found out that the foreign debt over time is inversely correlated with GDP.

Akram (2015) reviewed the relationship between foreign debt on GDP growth in Pakistan, using times series data from 1972 -2009. The study employed the use of ARDL model. The results showed that foreign debt has an inverse impact on GDP growth of a country. Further, it was found foreign debt could lead into debt overhang in the economy.

Woo and Kumar (2015) asserts that the recent worldwide financial crisis lead to unprecedented increase in public debt among countries across the globe raising the concern about its effect on GDP. They scrutinized the outcome of state debt on long-run economic growth across countries, using panel data spanning 38 years, from $1970-2007$ and using a panel regression analysis, they found out that public debt causes slowdown in the economy. They also established that the outcome of debt in the economy is linked to slowdown of labour productivity and slower capital accumulation. However, they failed to look how public debt at disaggregated level impacts on the economic growth.

Adamu and Rasiah (2016) examined the stout outcome of debt on GDP growth in Nigeria using secondary data from 1970 -2013. The data analysis of data was done by ARDL. The findings indicated that external debt and GDP are negatively correlated. Therefore, governments in developing countries should reduce their recurrent expenditure and bolster more revenues collection and invest in projects with high returns so that they can avoid foreign debt trap.

Rauf and Khan (2017) scrutinized the outcome of debt on economic output in Pakistan from 1972- 2013. The study engaged the use of autoregressive distributed lag model as data analysis tool. The findings indicated that external debt and GDP are inversely related. This points out that there is debt overhang in the country of study.

Saxena and Shanker (2018) examined the outcome of foreign debt on GDP growth in India using secondary data spanning from 1991-2016. The study applied multiple regression as data analysis technique. Results showed that external debt and GDP have an inverse relationship. This study considered external debt therefore, excluding other components of public, which could inform the comprehensive understanding.

Abdullahi, Hassan and Bakar (2016) studied the consequences of foreign debt on investment in Nigeria using secondary data from 1980-2013.Using an ARDL model. They found out external debt has negative relationship with capital formation in the economy. They concluded that internally savings in an economy has a correlation with investment in an economy. Khodaparasti and Mohammadpour (2016) "inquired the connection between state debt and GDP growth in Southern Eastern Europe countries during the period 2000-2014". The findings indicated that external debt and GDP have inverse connection. Therefore, state debt should be properly managed, and applied in infrastructure projects with high rate of return.

Perveen and Munir (2017) studied the impact of total, government debt on nominal interest rate in Pakistan using annual secondary data from 1973-2016. This study employed ARDL model data analysis tool. The results indicated that foreign debt and interest rates are negatively correlated in the long-term.

Blake (2015) examined the role of foreign debt on GDP growth in Jamaica using secondary data from 1990-1994 on quarterly basis. The study employed the use of ARDL model, which captures short-term and long- term characteristics of foreign debt. "The findings of the study indicated that public debt has indirect relationship with GDP".

\section{Research Methodology}

\subsection{Research Design}

This study employed the descriptive research design. Descriptive research design is about finding out the what, the where, and the how of a phenomenon.

\subsection{Target Population}

The study focused on secondary data on foreign debt from 1980 to 2017. The constituents of foreign debt consisted of bilateral debt, multilateral debt and supplier credits.

\subsection{Sample and Sampling Technique}

The sample size was data for the period from 1980 to 2017. The secondary data on foreign debt included bilateral debt, multilateral debt and Suppliers credit. 


\subsection{Data Collection Instruments}

The study employed secondary data for the period from 1980 to 2017. Data was collected by the use of secondary data collection form. The forms captured the three constituents of foreign debt: bilateral debt, multilateral and supplier's credit. The secondary data was collected from Statistical Abstracts from Kenya National Bureau of Statistics (KNBS), Central Bank of Kenya Statistical Bulletin, World Bank publications.

\subsection{Data Collection Procedure}

Time series data was extracted from "Statistical Abstracts from KNBS, Central Bank of Kenya Statistical Bulletin", World Bank and IMF publications. The extracted secondary data was verified and cross-checked for accuracy before recording in secondary data collection forms developed by the researcher.

\subsection{Data Processing and Analysis}

The study employed time series regression analysis on secondary data. Specifically, the VAR analysis and VECM model. Stationarity of variables was tested by ADF test, while co-integration connection mid variables, Johansen cointegration test was used. The optimum lag length was determined by the use of LR, FPE, AIC, SIC and HQ. The lag length selection criteria that returns the lowest value will selected.

According to Shrestha and Bhatta (2018) selecting an appropriate data analysis technique for secondary data is a major consideration in time series analysis as wrong technique can result in biased and unreliable estimates. The estimation was done as follows; stationarity of time series data was established by the use of ADF unit root test. This was be necessary to avoid having spurious regression results and determine whether variable under study are stationary or non-stationary. The long-run relationship among variables was estimated by VECM model.

\subsection{Model Specification}

The external debt model was specified under VAR and VECM. The equations for external debt model under VAR were specified as follow:

$\ln R G D P_{t}=\beta_{0}+\beta_{1} \ln R G D P_{t-1}+\beta_{2} \ln B L E D T_{t-1}+\beta_{3} \ln M L E D T_{t-1}+\beta_{4} \ln S C R D T_{t-1}+U_{t} \ldots . . E q_{1}$

The equations for external debt model in VECM form was specified as follows:

$\Delta \ln R G D P_{t}=\beta_{0}+\beta_{1} \Delta \ln R G D P_{t-1}+\beta_{2} \Delta \ln B L E D T_{t-1}+\beta_{3} \Delta \ln M L E D T_{t-1}+\beta_{4} \Delta \ln S C R D T_{t-1}+E C T_{t-1}+U_{t} \ldots . . E q_{2}$

$\mathrm{RGDP}=$ Real Gross Domestic Product

BLEDT $=$ Bilateral External Debt

MLEDT $=$ Multilateral External Debt

SCRDT $=$ Suppliers Credit

$\Delta=$ Difference Operator

$\mathrm{ECT}=$ Error Correction Term

$\mathrm{U}=$ Error Term

\subsection{Presentation of Results}

\subsubsection{Unit Root Test}

Augmented Dickey Fuller (ADF) technique was employed to test for stationarity in the study. The results of the test are presented in table 1 below:

\begin{tabular}{|c|c|c|c|c|}
\hline Series & ADF Test Statistic & $\mathbf{5 \%}$ Critical Value & $\mathbf{1 0 \%}$ Critical Value & Remarks \\
\hline LNGDP & 2.130612 & -2.943427 & -2.610263 & Not-stationary \\
\hline LNBEDT & -1.636238 & -2.943427 & -2.610263 & Not-stationary \\
\hline LNMEDT & -2.292503 & -2.943427 & -2.610263 & Not-stationary \\
\hline LNSCRDT & -2.496379 & -2.943427 & -2.610263 & Not-stationary \\
\hline First Difference & & & & \\
\hline Series & ADF Test Statistic & $5 \%$ Critical Value & $10 \%$ Critical Value & Remarks \\
\hline D(LNGDP) & -3.373194 & -2.945842 & -2.611531 & Stationary \\
\hline D(LNBEDT) & -9.488574 & -2.945842 & -2.611531 & Stationary \\
\hline D(LNMEDT) & -5.039322 & -2.945842 & -2.611531 & Stationary \\
\hline D(LNSCRDT) & -8.00406 & -2.945842 & -2.611531 & Stationary \\
\hline
\end{tabular}

Table 1: ADF Unit Root Test at Level and First Difference

\subsubsection{Cointegration Test}

Johansen cointegration test was applied to test cointegration relationship in the study. Johansen Cointegration test consist of two techniques namely: unrestricted Rank Trace test and Maximum Eigen value test. The results of the test are presented in table2 below: 


\begin{tabular}{|c|c|c|c|c|}
\hline Hypothesized No. of CE(s) & Eigenvalue & Trace Statistic & 5\% Critical Value & Prob** \\
\hline None* & 0.487943 & 52.90919 & 47.85613 & 0.0156 \\
\hline At most 1 & 0.389539 & 28.81372 & 29.79707 & 0.0646 \\
\hline At most 2 & 0.228064 & 11.04628 & 15.49471 & 0.2087 \\
\hline At most 3 & 0.046854 & 1.727553 & 3.841466 & 0.1887 \\
\hline Hypothesized No. of CE(s) & Eigenvalue & Max-Eigen Statistic & $5 \%$ Critical Value & Prob** \\
\hline None & 0.487943 & 24.09547 & 27.58434 & 0.1314 \\
\hline At most 1 & 0.389539 & 17.76744 & 21.13162 & 0.1388 \\
\hline At most 2 & 0.228064 & 9.318723 & 14.26460 & 0.2606 \\
\hline At most 3 & 0.046854 & 1.727553 & 3.841466 & 0.1887 \\
\hline
\end{tabular}

Table 2: Johansen Cointegration Test (Trace and Maximum Eigen Test)

\begin{tabular}{|c|c|c|c|c|}
\hline Series & Coefficient & Std. Error & t-Statistic & Prob. \\
\hline LNRGDP(-1) & 1.00000 & & & \\
\hline LNBLEDT(-1) & 1.03565 & 0.20756 & 4.98955 & 0.0000 \\
\hline LNMLEDT(-1) & 1.56602 & 0.21471 & -7.29363 & 0.0000 \\
\hline LNSCRDT(-1) & 0.38804 & 0.19098 & 2.03181 & 0.0247 \\
\hline C & 11.3592 & & & \\
\hline
\end{tabular}

Table 3: Long-run Coefficients

Inferring from table 3 above the long- run equation for the study was specified as follows:

$\ln R G D P_{t}=11.35920-1.03565 \ln B L E D T_{t}+{\ln M L E D T_{t}}_{t} 0.38804 \ln S C R D T_{t} \ldots . . \mathrm{Eq} 3$

\subsubsection{Vector Error Correction Model Results}

The aim of a VECM is to define the rapidity of correction upon a non-conformity from long- run equilibrium (Kalumbu, \& Sheefeni, 2014). The deviations in the system are corrected through short- run adjustments. The estimation of a VECM is dictated by the results of Cointegration test. Having tested for cointegration and found that at least one cointegration equation was confirmed. This was the basic reason for estimating a VECM. The results for VECM is presented in table 4 below:

\begin{tabular}{|c|c|c|c|c|}
\hline Variables & Coefficient & Std. Error & t-Statistic & Prob. \\
\hline ECT(C1) & -0.02827 & 0.01042 & -2.7117 & 0.0051 \\
\hline D(LNRGDP)(C2) & 0.50918 & 0.19273 & 2.642 & 0.0096 \\
\hline D(LNBLEDT)(C4) & 0.01809 & 0.0101 & 1.791 & 0.0408 \\
\hline D(LNMLEDT)(C6) & -0.03294 & 0.01907 & -1.1331 & 0.0463 \\
\hline D(LNSCRDT)(C8) & 0.00104 & 0.01259 & 0.0083 & 0.9934 \\
\hline C(C10) & 0.02183 & 0.01055 & 2.0701 & 0.0410 \\
\hline
\end{tabular}

Table 4: Vector Error Correction Model (VECM) Results

R-Squared $=0.436007$ Durbin Watson $(D W)=2.085910$ F-Statistic $=33.03405$ Prob (F-Statistic) $=0.0001$

From table 4 above the short run equation ECT was specified as follow:

$\Delta \ln R G D P_{t-1}=-0.002827 E C T_{t-1}+0.50918 \Delta \ln B L E D T_{t-1}-0.03294 \Delta \ln M L E D T_{t-1}+0.00104 \Delta \ln S C R D T_{t-1}+$ $0.02183 \ldots . . . \mathrm{Eq} 4$

\subsubsection{Causality Test}

Granger causality test is appropriate to be employed to test for causality in the model. The test results are presented in table 5 below:

\begin{tabular}{|c|c|c|c|}
\hline Null Hypothesis & Obs & F-Statistic & Prob. \\
\hline "LNBLEDT does not Granger Cause LNRGDP" & 35 & 0.00526 & 0.9425 \\
\hline "LNRGDP does not Granger Cause LNBLEDT" & 35 & 9.47708 & 0.0034 \\
\hline "LNMLEDT does not Granger Cause LNRGDP" & 35 & 1.72612 & 0.1949 \\
\hline "LNRGDP does not Granger Cause LNMLEDT" & 35 & 3.32893 & 0.074 \\
\hline "LNSCRDT does not Granger Cause LNRGDP" & 35 & 3.19409 & 0.08 \\
\hline "LNRGDP does not Granger Cause LNSCRDT" & 35 & 5.83699 & 0.0194 \\
\hline
\end{tabular}

Table 5: Pairwise Granger Causality Test Results

\subsubsection{Post Estimation Diagnostic Tests}

Post estimation diagnostic tests consisted of serial correlation test, Jarque-Bera Normality test and Heteroscedasticity. The results of post estimation tests were presented in table 6, 7 and 8 below: 


\begin{tabular}{|c|c|c|}
\hline Lags & LM-Statistic & Prob \\
\hline 1 & 20.23494 & 0.2098 \\
\hline 2 & 17.61191 & 0.3471 \\
\hline
\end{tabular}

Table 6: Serial Correlation LM Test Results

\begin{tabular}{|c|c|c|c|}
\hline Components & "Jarque-Bera" & df & Prob. \\
\hline 1 & 2.740825 & 2 & 0.2540 \\
\hline 2 & 66.56124 & 2 & 0.0000 \\
\hline 3 & 3.096898 & 2 & 0.2126 \\
\hline 4 & 0.738264 & 2 & 0.6913 \\
\hline
\end{tabular}

Table 7: Jarque-Bera Normality Test Results

\begin{tabular}{|c|c|c|}
\hline Chi-sq & df & Prob. \\
\hline 180.7250 & 180 & 0.4708 \\
\hline
\end{tabular}

Table 8: Heteroscedasticity Test Results

\section{Discussion of Results}

\subsection{Unit Root Test}

From results presented in table1, variables were not stationary and were of integration order one I(1), at both levels of statistical significance $5 \%$ and $10 \%$. The null hypothesis that variables have unit root at level was not rejected. This was due the fact that values for ADF statistic at level was less than the t-statistics at $5 \%$ and $10 \%$. On first difference, the variables in the model become stationary leading to rejection of the null hypothesis that variables have unit root on first difference. This was due to the fact that $\mathrm{ADF}$ statistic was greater than t-statistics at both levels of $5 \%$ and $10 \%$ level of statistical significance.

\subsubsection{Cointegration Test}

Inferring from cointegration test results presented in table 2 indicated that there is one cointegration equation among variables RGDP, BLEDT, MLEDT and SCRDT. The cointegration equation confirmed that variables have a long-term association. From table 2, it was observed that t-statistic for the first component was greater than $5 \%$ critical value that is (52.90919>47.85613) while the other test statistics were less than critical values at $5 \%$ level of significance. Since the first component, probability value was less than $5 \%$, the null hypothesis was rejected. This confirmed that there was a cointegration association among the variables at $5 \%$ level of significance.

\subsubsection{Error Correction Model (VECM)}

From the result presented in table 4, the Error Correction Term (ECT) was significant and its coefficient has a negative sign. These two conditions are essential in a VECM so that any deviations from long- run equilibrium are adjusted accordingly. The inverse sign on the ECT coefficient confirmed that there is long-run convergence in the model.

In view of the above result $\mathrm{ECT}_{\mathrm{t}-1}=0.02827$ the probability value (P-value) $=0.0056<0.05$ that is at $5 \%$ level of significance. The ECT coefficient of -0.02827 pinpointed the rapidity of corrections. This means any non-conformity in the current period are corrected at a rapidity of $2.827 \%$ towards the long-run equilibrium. In other words, the short-run deviation towards long-run equilibrium are corrected at speed of $2.827 \%$ annually."

Computed R-squared $=43.6 \%$ this indicated that $43.6 \%$ changes in RGDP can be accounted for by the independent variables that is bilateral debt (BLEDT), Multilateral debt (MLEDT) and suppliers' credit (SCRDT). The remaining $56.4 \%$ of the changes in economic growth can be attributed to other factors outside the model.

The F-statistic $=33.03405$ with probability value of 0.0001 which is less than $5 \%$ critical value and therefore independent variables jointly influence dependent variable". "The result of Durbin Watson (DW) $=2.085910$ indicated the absence of serial correlation in the model". "From the results presented in table 3 and the equation stated below:

$\ln R G D P_{t}=11.35920-1.03565 \ln B L E D T_{t}+\ln M L E D T_{t}-0.38804 \ln S C R D T_{t} \ldots \ldots . \mathrm{Eq} 5$

Bilateral debt (LNBLEDT), Multilateral debt (LNMLEDT and suppliers' credit (LNSCRDT) have negative relationship with RGDP during the period of study. LNBLEDT, LNMLEDT and LNSCRDT, holding other factors constant a $10 \%$ increase in the mentioned variables would bring about $10.3 \%, 15.66 \%$ and $3.8 \%$ decrease in RGDP respectively. The equation was stated as indicated below:

$\Delta \ln R G D P_{t-1}=-0.002827 E C T_{t-1}+0.50918 \Delta \ln B L E D T_{t-1}-0.03294 \Delta \ln M L E D T_{t-1}+0.00104 \Delta \ln S C R D T_{t-1}+$ $0.02183 \ldots . . . \mathrm{qq} 6$

In the current period, bilateral debt (LNBLEDT), multilateral debt (LNMLEDT) and suppliers' credit (LNSCRDT) have negative relationship with RGDP. Holding other factors constant, a 10\% increase in LNBLEDT, LNMLEDT and LNSCRDT would bring about $0.18 \%, 0.329 \%$ and $0.01 \%$ decrease in real RGDP) respectively during the period of study. This indicated that external debt does not have favourable effect on growth in Kenya in the current period. 


\subsubsection{Causality Test}

From the results presented in table 5, the pairwise Granger causality test was applied to test the direction of the causality". The test confirmed that there is a single directional causality from RGDP to BLEDT with a probability value of 0.00340

\subsubsection{Post Estimation Diagnostic Tests}

The post estimation diagnostic tests are aimed at ensuring that the estimated model is stable. From the results presented in table 6, LM statistics have a probability value that is greater than $5 \%$ critical value. This implied that the null hypothesis of no serial correlation in the residual is accepted. This ratify that the model does not suffer from serial correlation. In table 7 Jarque-Bera Normality indicated that three (3) components are normally distributed and jointly the components are not normally distributed. From table 7 the heteroscedasticity test indicated that chi-square statistic $=180$ with a probability value of 0.4708 which is more than $5 \%$ critical value, thus null hypothesis was not rejected. This confirmed that the model does not suffer from heteroscedasticity.

\subsection{Implication of the Study}

\subsubsection{Summary of Findings}

The study examined the outcome of state debt and RGDP growth in Kenya from 1980-2017. The variables in the study include RGDP as measure of economic output in Kenya, bilateral debt, multilateral debt and supplier credits. "The study employed VECM, ADF unit root test and Johansen cointegration test." Results of the study indicated that;

- Bilateral debt has a significant negative relationship with RGDP growth in Kenya both in the final analysis and in the current period during the study.

- Multilateral debt has a significant inverse relationship with growth in Kenya both in the final analysis and the current period of study.

- Supplier credit has significant positive relationship with growth in Kenya in the final analysis. In the current period supplier's credit has insignificant positive relationship with growth in Kenya.

- There is causal relationship among variables. There is single directional causality running from RGDP to BLEDT and there is single directional causality running from RGDP to SCRDT.

\subsubsection{Recommendations}

From the findings, the study suggests that the government should maintain sustainable level of external debt in order to achieve desirable level of GDP growth. The external debt obtained by the government should be allocated strictly to capital projects such as infrastructure development.

\subsubsection{Conclusions}

This study established the outcome of state debt and GDP in Kenya from 1980-2017. "The study applied VECM for data analysis, "Augmented Dickey Fuller (ADF) unit root test" for testing stationarity and Johansen Cointegration test was used test for cointegration". The variables in the study RGDP as a measure of economic growth, bilateral debt (BLEDT), multilateral debt (MLEDT) and suppliers' credit (SCRDT). The findings indicated that within the period of study bilateral and multilateral debt have significant negative relationship with RGDP growth in Kenya both in the final analysis and current period. The suppliers' credit affects RGDP growth in Kenya in the current period and in the final analysis affects RGDP positively though it has insignificant positive effect on RGDP growth. The inference of the outcomes in the study indicated that unsustainable external debt cannot spur RGDP growth and therefore the government should strive to maintain an optimum level of external debt to achieve a desirable level of GDP growth.

\section{Reference}

i. Abdullahi, M. M., Hassan, S. B., \& Bakar, N. A. B. A. (2016). Government debt and capital formation in Nigeria: An ADRL lag approach. "Mediterranean Journal of Social Sciences", 7(1),

ii. Adamu, I. M., \& Rasiah, R. (2016). Government debt and GDP growth dynamics in Nigeria. African Development Review, 28(3), 291-303.

iii. Adedoyin, L. I., Babalola, B. M., Otekunri, A. O., \& Adeoti, J. O. (2016). "Government debt and GDP growth": "Evidence from Nigeria". "Acta Universitatis Danubius. Economica, 12(6)".

iv. Ahmed, J. (2017). "Does External Debt Lead to Growth?". "KIEP Research Paper, World Economy Brief, 17-22".

v. Akram, N. (2015). "Relationship between Government debt and GDP growth in Pakistan". "The Pakistan Development Review, 599-615".

vi. Blake, T. (2015). "Effect of government debt on growth in Jamaica". "Working paper of Fiscal and Economic Program Monitoring Department", "Bank of Jamaica”.

vii. Doğan, İ., \& Bilgili, F. (2014). "The impact of government debt on GDP growth": A markov regime-switching approach. Economic Modelling, 39, 213-220.

viii. Jamaica, Senadza, B., Fiagbe, K., \& Quartey, P. (2017). "Government debt and Growth in Sub-Saharan Africa". "International Journal of Business and Economic Sciences Applied Research" (IJBESAR), 9, 61 - 69.

ix. Jilenga, M.T., Xu, H., \& Gondje-Dacka, I.M. (2016). "The relationship external debt and investment on GDP growth in Tanzania", "International Journal of Financial Research", 7(2), 154. 
x. Khodaparasti, R. B., \& Mohammadpour, R. (2016). "The relationship between foreign debt and GDP in selected European Countries". Amfiteatru Economic Journal, 18(43), 548-556.

xi. Lee, S. P., \& Ng, Y. L. (2015). "The Public Borrowing and Growth in Malaysia". "Asian Economic and Financial Review, 5(1), 119-126".

xii. Mensah, D., Aboagye, A.Q., Abor, J.Y., \& Kyereboah-Coleman, A. (2017). "External debt among HIPCs in Africa: accounting and panel VAR analysis of some determinants". "Journal of Economic Studies", 44(3), 431-455.

xiii. Perveen, A., \& Munir, K. (2017). "Impact of total, internal and external government debt on interest rate in Pakistan". Retrieved from: https:/ / mpra.ub.uni-muenchen.de/ 83427/

xiv. Saxena, S. P., \& Shanker, I. (2018) External debt and Gross domestic product in India". "Social Science Asia, 4(1), $15-25$.

xv. Woo J., \& Kumar, M. S. (2015). “The External debt and growth”. “Economica, 82(328), 705-739”.

xvi. Megersa, K. A. (2015). "The Laffer curve and the debt-growth link in low-income Sub-Saharan African economies". "Journal of Economic Studies", 42(5), 878-892.

xvii. Kalumbu, S. A., \& Sheefeni, J. P. S. (2014). "Terms of trade and GDP in Namibia. International Review of Research in Emerging Markets and the Global Economy”, 1(3), 90-101. 